\title{
Two new species of box jellies (Cnidaria: Cubozoa: Carybdeida) from the central coast of Western Australia, both presumed to cause Irukandji syndrome
}

\author{
Lisa-Ann Gershwin \\ CSIRO Marine and Atmospheric Research, Castray Esplanade, Hobart, Tasmania 7000, Australia. \\ Email: lisa-ann.gershwin@csiro.au
}

\begin{abstract}
Irukandji jellies are of increasing interest as their stings are becoming more frequently reported around the world. Previously only two species were known from Western Australia, namely Carukia shinju Gershwin, 2005 and Malo maxima Gershwin, 2005, both from Broome. Two new species believed to cause Irukandji syndrome have recently been found and are described herein. One, Malo bella sp. nov., is from the Ningaloo Reef and Dampier Archipelago regions. It differs from its congeners in its small size at maturity, its statolith shape, irregular warts on the perradial lappets, and a unique combination of other traits outlined herein. This species is not associated with any particular stings, but its phylogenetic affinity would suggest that it may be highly toxic. The second species, Keesingia gigas gen. et sp. nov., is from the Shark Bay and Ningaloo Reef regions. This enormous species is unique in possessing key characters of three families, including crescentic phacellae and broadly winged pedalia (Alatinidae) and deeply incised rhopalial niches and feathery diverticulations on the velarial canals (Carukiidae and Tamoyidae). These two new species bring the total species known or believed to cause Irukandji syndrome to at least 16. Research into the biology and ecology of these species should be considered a high priority, in order to manage their potential impacts on public safety.
\end{abstract}

KEYWORDS: Malo bella, Keesingia gigas, Ningaloo Reef, Indian Ocean, taxonomy

\section{INTRODUCTION}

Irukandji jellies are becoming of increasing interest to divers, swimmers, and occupational health and safety managers, as their stings are becoming more frequently reported around the world (Gershwin et al. 2013). Irukandji syndrome is a constellation of systemic symptoms with a delayed onset after a sting from a jelly. Symptoms typically include severe lower back pain, nausea and vomiting, difficulty breathing, profuse sweating, cramps and spasms, and a feeling of impending doom (Williamson et al. 1996). Some cases also have severe hypertension (high blood pressure), which can be life threatening. Two confirmed fatalities from Irukandji-related hypertension occurred in 2002 (Fenner and Hadok 2002; Huynh et al. 2003). It is generally believed that additional fatalities have occurred, but have been masked as heart attack, stroke, or drowning (Gershwin et al. 2009).

Irukandji are often associated with Queensland, as that is where the syndrome was discovered and named, and most of the research has occurred (Flecker 1952; Barnes 1964; Southcott 1967; Gershwin et al. 2013).
However, the first unequivocal report of symptoms attributable to Irukandji syndrome in Australia occurred in Onslow in 1927 and 1928 (Stenning 1928). Much later, Macrokanis et al. (2004) demonstrated that Irukandji syndrome in Broome is at least as serious a problem as it is in Queensland. Two species of Irukandji jellies were described from Western Australia in 2005, namely Carukia shinju and Malo maxima, both from the far northwest near the town of Broome (Gershwin 2005b).

Farther south, reports of Irukandji are sparse. An unnamed species was identified from near the Montebello Islands in the region of Dampier (Gershwin 2005a), but lack of adequately preserved material prevented a full description and classification. In the Ningaloo Reef region, stings occur only occasionally, with 0-2 per year being typical (P. Hannay, Exmouth Hospital personal communication). These are not generally linked to specimens or species. Similarly, two Irukandji stings from unknown species have been reported in the Perth region, one at Scarborough Beach at a Surf Life Saving carnival in the 1980s and another near Rottnest Island in 2003 (Gershwin et al. 2009). 
Identification of these species is the first step toward understanding them and managing their stings.

It is therefore of potentially great importance to find another two new species of cubomedusae believed to cause Irukandji syndrome in Western Australian coastal waters. One, based on a specimen found near Exmouth following a cluster of 23 confirmed Irukandji stings (Gershwin and Hannay 2014), is similar to undescribed museum specimens from the Montebello Islands. Despite some variation, a conservative approach is taken herein and they are regarded as the same species, described as Malo bella sp. nov. below.

The other is based on an enormous specimen taken in a fishing net near Shark Bay in late summer 2012. This specimen poses a taxonomic puzzle, with some characteristics of the family Alatinidae and other characteristics more like the genus Morbakka in the family Carukiidae. This curious species is associated with systemic illness following a sting at Ningaloo Reef to the north. This species is here described as Keesingia gigas gen. et sp. nov.

Recently two methods of forecasting Irukandji jellies occurrence have been developed. One applies to species in the genus Alatina, which swarm on the 8th-10th nights after the full moon in Australia or the 9th-12th days after the full moon in Hawaii (Chiaverano et al. 2013). The other forecasting system applies to the diminutive Carukia barnesi in Queensland, which forms nearshore aggregations when the along-shore winds subside. The extent to which either of these new species may be predictable is currently unknown.

The purpose of this paper is to describe two new species of cubozoan jellies, presumed to cause Irukandji syndrome. This now brings the total number of Irukandji species described from Western Australia to four, with nine from Australia, and at least 16 globally. The biology and ecology of Irukandjis were recently reviewed (Gershwin et al. 2013) highlighting our paucity of knowledge on this remarkable group; these areas should be considered high priority for future study and safety management.

\section{MATERIALS AND METHODS}

All taxonomic observations and measurements were made on preserved material unless otherwise noted. Measurements were made with a ruler to the nearest $\mathrm{mm}$ or with Max-Cal digital calipers to the nearest $0.01 \mathrm{~mm}$. Bell height $(\mathrm{BH})$ was measured from the apex of the bell to the velarial turnover. Diagonal bell width (DBW) was measured across diagonal pedalia on a flattened specimen, at the height where the pedalium joins the exumbrella of the bell. Interrhopalial width (IRW) was measured between adjacent rhopalia, with the specimen flattened. Tentacle base width (TBW) was measured at the uppermost part of the tentacle, immediately below the pedalium. In opaque specimens, a search for phacellae was made by making a small incision in the upper corners of the bell, and then pulling back a small amount of mesoglea to expose the floor of the stomach, or by opening up the full length of the body wall to expose the stomach, and then opening the stomach in the same manner. In transparent specimens, absence of phacellae was obvious. Nematocysts were examined and measured with a Leica DMLB compound microscope and Leica IM-50 Image Manager v. 1.20 for Windows; all observations and photographs were made through a 40x objective (i.e. $400 \mathrm{x}$ magnification). Nematocysts were identified following the keys of Calder (1974), Mariscal (1971), Williamson et al. (1996), and Gershwin (2006).

Abbreviations used. Western Australia (WA); Western Australian Museum, Perth (WAM); Museum and Art Gallery of the Northern Territory (NTM); Western Australian Department of Parks and Wildlife (DPaW); Marine Information and Research Group, Perth, Australia (MIRG Australia).

\section{SYSTEMATIC RESULTS}

Class Cubozoa Werner, 1973

\section{Order Carybdeida Gegenbaur, 1856 (sensu Werner, 1984)}

\section{Family Alatinidae Gershwin, 2005}

\section{Genus Keesingia gen. nov.}

http://www.zoobank.org/urn:Isid:zoobank. org:act:A94C930A-4641-4CED-ABFF-DA3876A78A2A

\section{TYPE SPECIES}

Keesingia gigas sp. nov.

\section{DIAGNOSIS}

Alatinidae with a large, thick, warty bell; with deeply incised frown-shaped rhopalial niches, divided below at the midline; with well developed subumbrellar mesenteries; with adradial gelatinous lappets.

\section{REMARKS}

The type species of the genus, Keesingia gigas, is remarkable, in many ways resembling Morbakka (Gershwin 2008) while also strongly resembling species in the Alatinidae (Table 1). For example, the rhopalial niche most resembles that of Morbakka or Tamoya with the deep cavity and dumbbell-shaped ostium (Bigelow 1938: text-fig. 20; Gershwin 2008: figs. 2D, E), and yet it also has a superficially split lower scale (Figure 2A herein), which is not found in any other cubozoan but suggests an affinity with Alatina, in which the lower scale is fully split, creating a T-shaped ostium (Bigelow 1938: text-fig. 11; Gershwin 2005c: fig. 2B; Bentlage 2010: fig. 1C). The ostium of the holotype of Alatina grandis (Agassiz and Mayer, 1902) figured by Bentlage (2010) is of the 'normal' Alatina type, that is to say, it is fully and prominently T-shaped, whereas the ostium of 
TABLE 1

Comparison of characters of large-bodied species in the Carybdeida.

\begin{tabular}{|c|c|c|c|c|}
\hline & Morbakka (Carukiidae) & Tamoya (Tamoyidae) & A. grandis (Alatinidae) & Keesingia \\
\hline Bell & Large, thick, warty & Large, thick, warty & Large, thick, not warty & Large, thick, warty \\
\hline Rhopalial niche & $\begin{array}{l}\text { Dumbbell-shaped, } \\
\text { lower undivided }\end{array}$ & $\begin{array}{l}\text { Dumbbell-shaped, } \\
\text { lower undivided }\end{array}$ & $\begin{array}{l}\text { T-shaped with lower } \\
\text { strongly divided }\end{array}$ & $\begin{array}{l}\text { Dumbbell-shaped, } \\
\text { lower divided }\end{array}$ \\
\hline Rhopalial horns & Present & Absent & Absent & Absent \\
\hline Pedalia & Narrow -winged & Narrow-winged & Broad-winged & Broad-winged \\
\hline Pedalial canal & $\begin{array}{l}\text { Spike at bend, } \\
\text { quadrate, flared at end }\end{array}$ & $\begin{array}{l}\text { Spike at bend, } \\
\text { quadrate, flared at end }\end{array}$ & $\begin{array}{l}\text { Without spike, flat, not } \\
\text { flared }\end{array}$ & $\begin{array}{l}\text { Without spike, flat, not } \\
\text { flared }\end{array}$ \\
\hline Stomach & Voluminous & Voluminous & Small, short & Small, short \\
\hline Phacellae & Absent & Vertical & Broadly crescentic & Broadly crescentic \\
\hline Mesenteries & $\begin{array}{l}\text { Robust, flap-like in } \\
\text { upper half, cord-like in } \\
\text { lower half }\end{array}$ & $\begin{array}{l}\text { Robust, flap-like in } \\
\text { upper half, cord-like in } \\
\text { lower half }\end{array}$ & [not described] & $\begin{array}{l}\text { Flap-like in upper half, } \\
\text { absent in lower half }\end{array}$ \\
\hline Velarial canals & $\begin{array}{l}\text { Feathery, } \\
\text { diverticulated }\end{array}$ & $\begin{array}{l}\text { Dendritic, } \\
\text { diverticulated }\end{array}$ & Short, tree-like & $\begin{array}{l}\text { Feathery, } \\
\text { diverticulated }\end{array}$ \\
\hline Perradial lappets & Present & Absent & Absent & Absent \\
\hline Frenula & Single, hollow & Double & Well developed & Broad, hollow \\
\hline
\end{tabular}

Keesingia is shallow and more comparable to a smile with a hairlip or a very flat Q, where the split is so minor as to not disturb the integrity of the deep cavity. Another feature suggesting an alatinid affinity is the lack of rhopalial horns, whereas these structures are present in Morbakka and other carukiids (Gershwin 2005a; Gershwin 2008).

The warty bell would appear to place it firmly with Morbakka (Gershwin 2008), while its tall, barrellike shape is more characteristic of Alatina (Figure 1; Gershwin 2005c). So too, its crescentic phacellae place it firmly within the Alatinidae (Gershwin 2005c). However, while the pedalia are clearly of the largewinged Alatina type, the velarial canals are clearly of the feathered Morbakka type, but the perradial lappet, so prominent in the latter taxon, is lacking.

The mesenteries are worthy of discussion. Large species such as Morbakka and Tamoya have well developed mesenteries developed along the sides of the stomach and connecting to the subumbrella (Gershwin 2008; Collins et al. 2011). It appears that they may help keep the stomach centred and the mouth in place. Keesingia also has well developed mesenteries (Figure 2D); however, like the Alatinids, the stomach is very small. Therefore, the stomach is not stabilised by the mesenteries and they seem rather without purpose.

So too, the adradial gelatinous lappets (Figure 2C) are intriguing, as they had never been reported in any other species until they were formally described as 'velarial lappets' recently (Lewis et al. 2013). In general form, velarial lappets resemble the more familiar perradial lappets, which are essentially just triangular thickenings of the bell tissue extending out along the velarium, except that perradial lappets occur over the perradii, and velarial lappets occur between the perradii and interradii. Moreover, perradial lappets are conspicuous in the Carukiidae and Tamoyidae, whereas velarial lappets were found in the Alatinidae. Curiously, velarial lappets are also found in Keesingia, but they do not extend down onto the velarium as they do in Alatina alata.

Based on overall morphology, Keesingia seems to have more of the diagnostic traits of the Alatinidae than the Carukiidae. Characters such as the broadly winged pedalia, the crescentic phacellae, the divided lower rhopalial covering scale, the lack of rhopalial horns and perradial lappets, and the very small stomach are all consistent family features of Alatinidae, whereas characters such as the thick warty bell, mesenteries, broad frenula, and diverticulated velarial canals are found in some species of Carukiidae and not others and are also found in the Tamoyidae (Table 1).

However, recent $16 \mathrm{~S}$ barcoding of the Keesingia holotype confirmed the specimen's closer affinities with the Carukiidae (O. Berry, CSIRO, unpublished data). The morphological and molecular confusion between these large species suggests that the suite of morphological characters currently used for species 
differentiation in these Cubozoa may be inadequate to properly answer questions of species delineation.

The large specimens photographed at Ningaloo Reef in 1987 and 2013 appear to be attributable to Keesingia (Figure 3), as does another specimen photographed there in the 1990s (Marsh and Slack-Smith 2010: p. 53). The sizes, bell shape, pedalia shape, and conspicuous orange wartiness are similar, and the gonads of the smaller specimen appear to be immature, suggesting that the species can grow much larger. Curiously, neither the collected specimen nor any of the photographed specimens appear to have tentacles; whether it is a feature of the species that they are so fine as to be overlooked, or that they are genuinely lacking, or that it is mere coincidence that they have been broken off in all three, is unclear.

A swarm of $\sim 10-15 \mathrm{~cm}$ tall cubomedusae videotaped at Rowley Shoals on 9 September 2013 may also be attributable to this species (see Gershwin and Hannay 2014, figure 2). These medusae are tall like alatinids, but with robust, squared off bells like Morbakka and Malo in the Carukiidae. These are the very characters that one would expect for Keesingia of any size.

\section{ETYMOLOGY}

The genus name, Keesingia, is named to honour Dr John Keesing of CSIRO Marine and Atmospheric Research, who not only provided the holotype for this species, but has been of great assistance and inspiration to the author for nearly 20 years.

\section{Keesingia gigas sp. nov.}

Figures 1-3

http://www.zoobank.org/urn:Isid:zoobank.
org:act:801E03E8-634D-41C1-B72B-C4D33447E84A

\section{MATERIAL EXAMINED}

\section{Holotype}

WAM Z27970, $5 \mathrm{~nm}$ west of Cape Inscription, Dirk Hartog Island, Shark Bay, Western Australia, 2536'28"S, 112 51'54"E, J. Keesing, 7 May 2012, hand held scoop net; immature specimen, $19 \mathrm{~cm} \mathrm{BH,} 97.65$ mm DBW, 49.44 mm IRW, 4.39 mm TBW.

\section{OTHER MATERIAL EXAMINED}

Photograph of specimen, Black Rock, Ningaloo Reef, Western Australia, P. Baker (WAM), 31 March 1987; approx. $50 \mathrm{~cm} \mathrm{BH}$; caused systemic sting reaction. Photograph of specimen, Ningaloo Reef, Western Australia, G. Taylor (physician in Busselton); did not cause systemic reaction. Photograph of specimen, Ningaloo Reef near Coral Bay, Western Australia, J. Totterdell (MIRG Australia), 12 April 2013; approx. 20 $\mathrm{cm} \mathrm{BH,} \mathrm{8-9} \mathrm{cm}$ wide; recorded during dense bloom of Crambione mastigophora. No specimens retained.

\section{DIAGNOSIS}

Alatinidae with a large, thick, warty bell; with deeply incised frown-shaped rhopalial niches, divided below at the midline; with well developed subumbrellar mesenteries; with adradial gelatinous lappets.

\section{DESCRIPTION}

\section{Holotype (from preserved specimen and photographs of live specimens)}

Bell very tall and narrow (Figure 1), with rigid jelly about $9 \mathrm{~mm}$ thick around middle portion of bell. Exumbrellar surface fairly densely and evenly covered with thousands of small gelatinous warts over most of the body except for inside the corner furrows; the warts do not appear to be studded with nematocysts, nor do they appear to be abraded. Corner furrows well defined, moderately deep, running the full length of the bell from just below the apex to the top of the pedalia.

Pedalia short, with broad inner and outer wings, each more than the width of the pedalial canal; wings warty and fragile in life, largely abraded away in the preserved specimen. Pedalial canal flat, simple, about $7.5 \mathrm{~mm}$ wide proximally, tapering to half its width at the tip. Pedalial canal bend without a thorn or other adornment; flaring only slightly at distal end, and also flared slightly about $2 / 5$ of the way toward distal end. Tentacles missing in this specimen, presumably lost during netting.

Rhopaliar niches very deeply incised into the bell. Ostium strongly dumbbell-shaped with a shallow vertical split at the midline of the lower covering scale (Figure 2A). Rhopalia uninterpretable due to degradation of the specimen. Rhopaliar horns lacking. Rhopaliar windows nondescript. Nerve cord pronounced, running from behind rhopalium down to base of pedalium, back up to rhopalium, and so forth.

Velarium with three gelatinous 'lappets' on the adradii of the exumbrellar side in each octant extending down onto the proximal edge of the velarium, as if overhanging it; these lappets are sculpted out of the mesoglea but are not connected with velarial canals (Figure 2C). On the subumbrellar side, approximately five canal roots extend onto velarium, all dendritic with first and second order diverticula, branching irregularly into about 6-9 canals reaching margin, all heavily diverticulated and appearing almost feather-like (Figure 2B). Perradial lappets lacking. A broad, hollow frenulum marks each perradius.

Phacellae broadly crescentic in the stomach corners; each with dozens of long, fine cirri, some distally bifurcated. Stomach small, short. Mesenteries well developed in upper fourth of subumbrellar interradii, about twice the length of the lips (Figure 2D). Lips folded, with smooth margins, only extending to about $1 / 8$ the length of the subumbrellar cavity (Figure 2D).

Gonads: undeveloped in this specimen.

Colour: bell is transparent and colourless, somewhat 


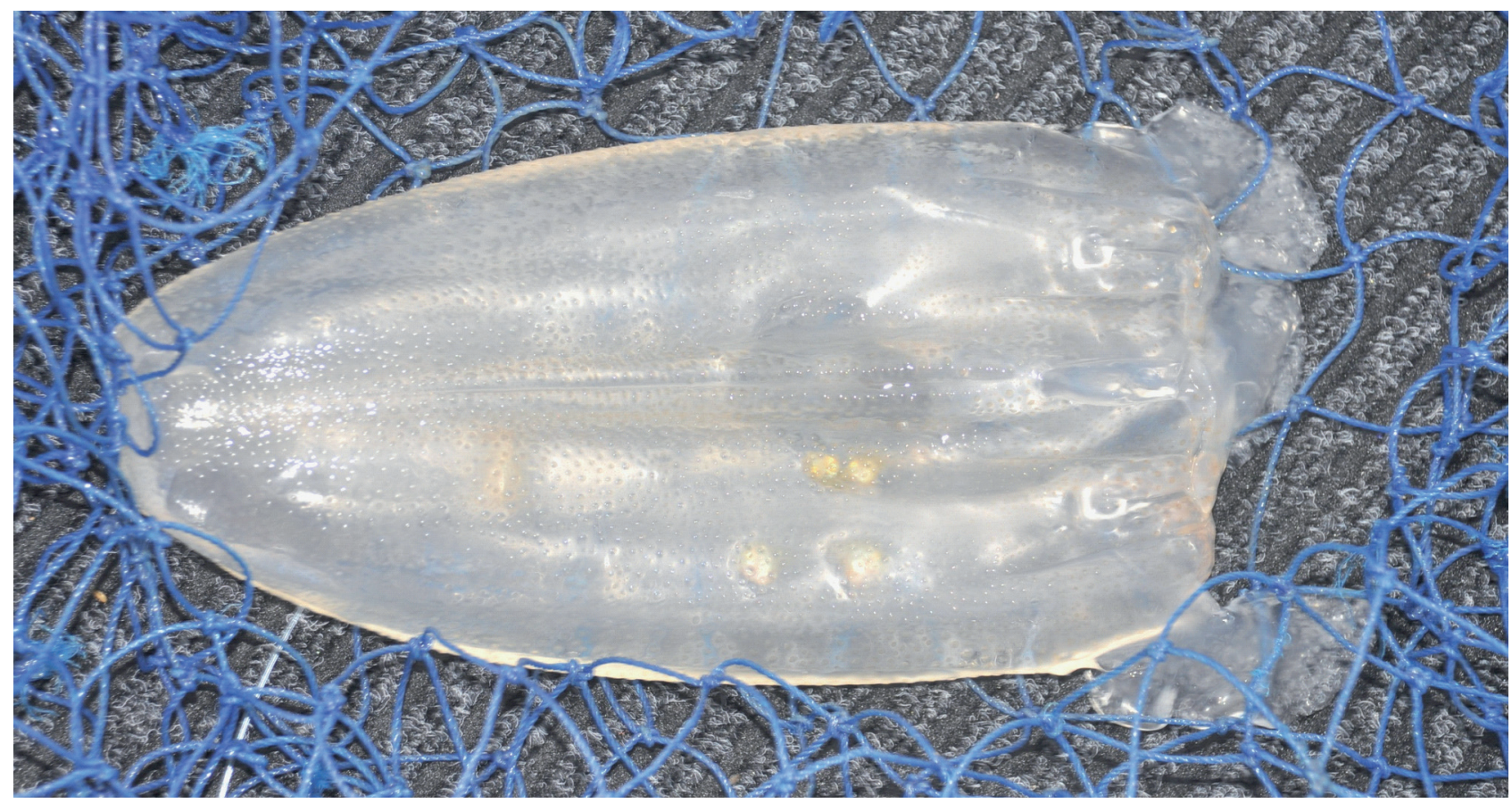

FIGURE 1 Keesingia gigas sp. nov., freshly caught holotype specimen; note orange warts densely scattered over body.

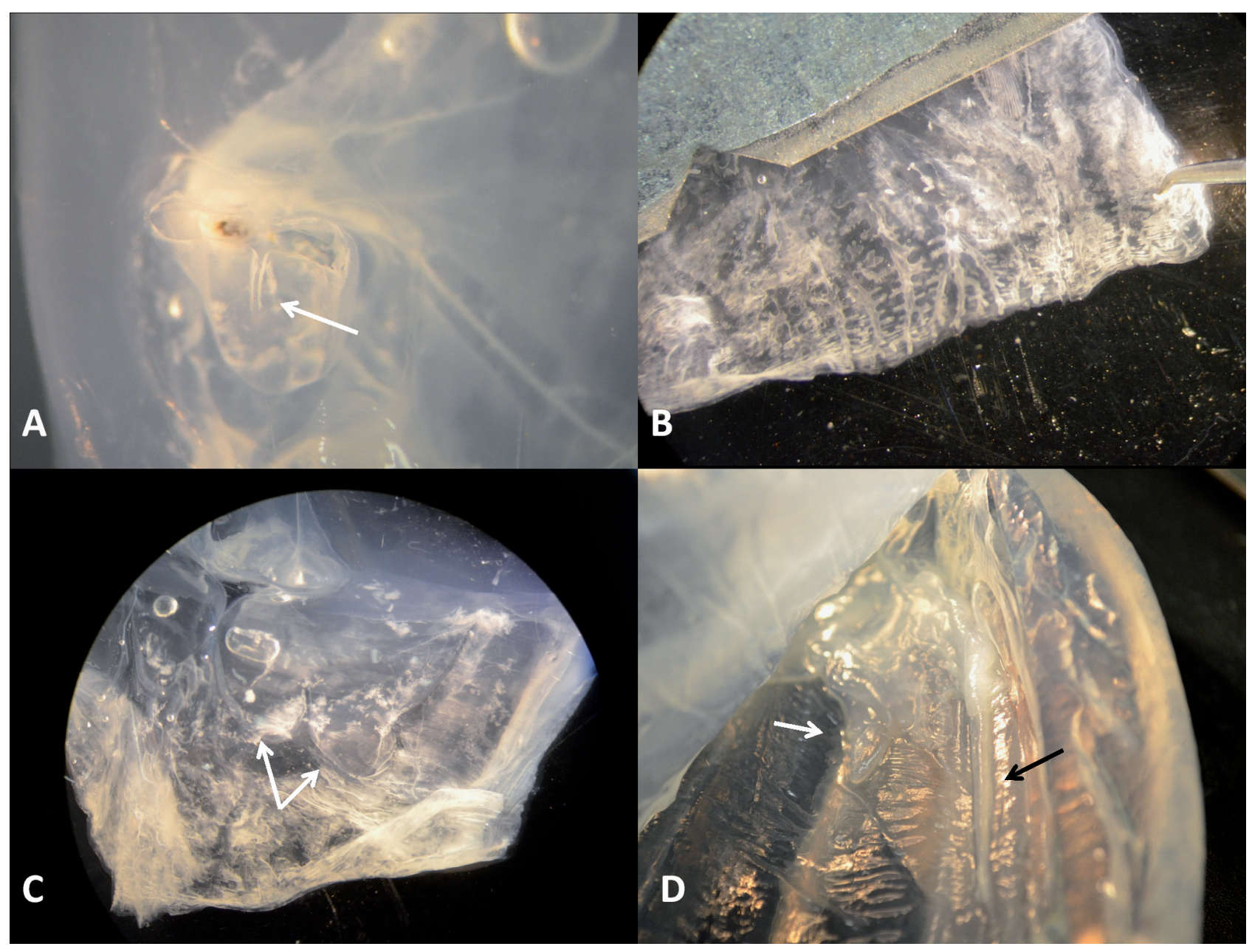

FIGURE 2 Keesingia gigas sp. nov., holotype. A. rhopaliar niche ostium; partially divided lower covering scale is indicated by arrow. B. velarial canals; note diverticula. C. adradial gelatinous lappets, indicated by arrows. D. mesenteries, indicated by black arrow; mouth is visible to the upper left (white arrow pointing to one lip). 


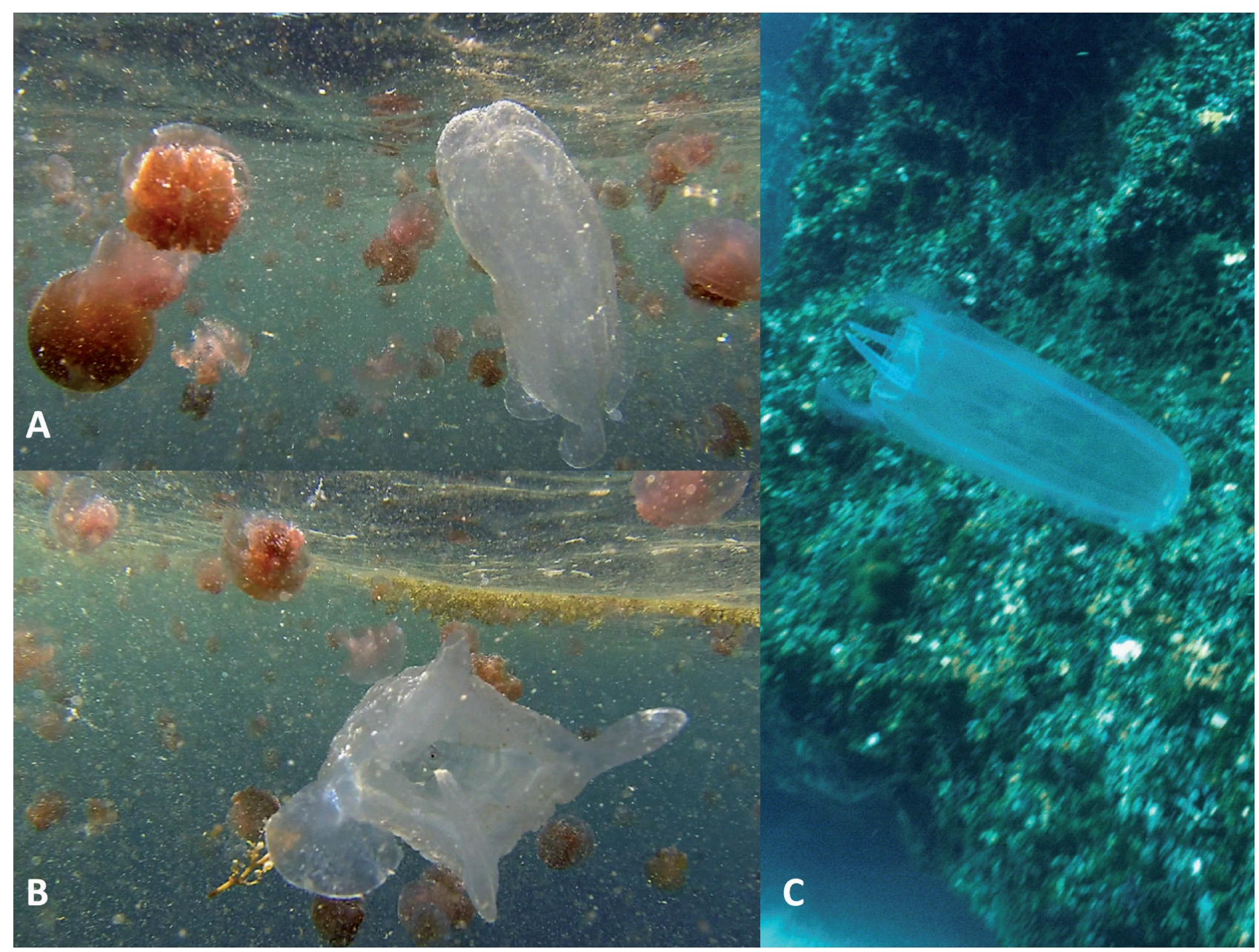

FIGURE 3 Keesingia gigas sp. nov., from Ningaloo Reef A, B. lateral view (A) and subumbrellar view (B) in bloom of Crambione mastigophora (sea tomatoes). (Image courtesy John Totterdell/MIRG Australia.) C. lateral view.

cloudy in appearance, with orange-coloured exumbrellar warts in life. Mesenteries and pedalial canals whitish.

Nematocysts: could not be found on the bell warts or pedalia.

\section{TYPE LOCALITY}

Dirk Hartog Island, Shark Bay, Western Australia, $25^{\circ} 36^{\prime} 28^{\prime \prime} \mathrm{S}, 112^{\circ} 51^{\prime} 54^{\prime \prime} \mathrm{E}$.

\section{DISTRIBUTION}

Specimen confirmation exists only from the type locality. However, the photographs of large alatinids with orange warts at Ningaloo Reef in 1987 and in 2013 also appear to be attributable to this species, and a swarm of cubomedusae at Rowley Shoals on 9 September 2013 may be the young of this species (see Gershwin and Hannay 2014, Figure 2).

\section{ETYMOLOGY}

The species name, gigas, is in reference to the enormous size of this species.

\section{ASSOCIATIONS}

Three juvenile leatherjacket fish (family Monacanthidae) were captured with this specimen, living inside the subumbrellar cavity. While the tendency of young leatherjackets to shelter with medusae has been previously reported (Hutchins 1994), this is the first report of fish sheltering in an Irukandji species. Whether they were also preying upon it is unknown, as the specimen was thought to be already dead when captured.

\section{STING REMARKS}

Two cases of stinging by Keesingia (as Tamoya gargantua) were reported by Williamson et al. (1996: p. 242, and pl. 9.6A, B). One produced severe Irukandji syndrome, whilst the other caused only local and groin pain. These and two more cases of stinging by Keesingia (as Alatina sp.) were reported by Marsh and Slack-Smith (2010: pp. 52-55). Of these, one from Exmouth in 1978 was consistent with Irukandji syndrome, whilst the other from Ningaloo in 1995 involved only intense local and lymph pain. 
Family Carukiidae Bentlage, Cartwright, Yanagihara, Lewis, Richards and Collins, 2010

\section{Genus Malo Gershwin, 2005}

Malo bella sp. nov.

Figure 4

\begin{abstract}
http://www.zoobank.org/urn:Isid:zoobank. org:act:A4DE4BCD-C9D5-4683-901A-AABD532650C6
\end{abstract}

"Dampier Irukandji": Gershwin 2005a: Tables 2.1-2.12, 98, 103, 107, 119, 195, 201, Plate 4.7; Gershwin 2005b: 3, 20; Gershwin 2007: 64, 65, Table 1.

Malo n. sp. A “Dampier Irukandji”: Gershwin 2006: 10, Table 1, Plate 19 [note that the specimen noted "holotype" is now paratype NTM C14617].

"Undescribed species of Malo is known from the islands off Exmouth": Gershwin et al. 2013: 40.

\section{MATERIAL EXAMINED}

\section{Holotype}

WAM Z27971, approximately $300 \mathrm{~m}$ east of the sandy beach in front of Harold E. Holt Memorial Communications Base, Exmouth Gulf (estimated GPS coordinates from Google Earth: 2153'28.37"S, $114^{\circ} 08^{\prime} 57.47^{\prime \prime E}$ ), R. De Jong (DPaW Parks and Visitors Services Coordinator), 9 July 2013, mid afternoon, 1-2 $\mathrm{m}$ below surface in 4-5 $\mathrm{m}$ total water depth; gravid female, $20.04 \mathrm{~mm} \mathrm{BH}, 18.50 \mathrm{~mm}$ DBW, $10.96 \mathrm{~mm}$ IRW, $1.43 \mathrm{~mm}$ TBW.

\section{Paratypes}

NTM C14617, Trimoville Island, Western Australia, H. Larson, 21 April 1983, by nightlight at anchorage, on surface over $5 \mathrm{~m}$, flat sandy bottom $\left(20^{\circ} 24^{\prime} \mathrm{S} 115^{\circ} 34^{\prime} \mathrm{E}\right)$; $19.11 \mathrm{~mm} \mathrm{BH}, 17.20 \mathrm{~mm}$ DBW, $8.35 \mathrm{~mm}$ IRW, $1.05 \mathrm{~mm}$ TBW with halo-like bands, male. NTM C5143, same data as C14617; 3 specimens, all mature but poorly preserved.

\section{DIAGNOSIS}

Malo with a very small body size at maturity; with long, well developed subumbrellar mesenteries; with one tri-branched velarial canal centrally located in each octant; perradial lappets broadly rounded, with irregular rows of nematocyst warts; rhopalial horns short and straight; statoliths almost perfectly hemispherical; tentacular nematocyst bands with or without halo-like shelves of tissue.

\section{DESCRIPTION}

\section{Holotype}

Body small, bell-shaped (Figure 4A), to about 19 $\mathrm{mm} \mathrm{BH}$, gravid at that size; with scattered nematocyst freckles, particularly lower on the bell near the velarium where they are slightly raised. Apex broadly rounded, nearly hemispherical; shallowly warted, lacking nematocysts. Bell of a robust consistency; evenly thick, with exumbrellar sculpturing of strongly defined pillars with shallow corner furrows, with rhopalial niches somewhat raised from the body wall.

Pedalia (Figure 4E) nearly half the bell height, unarmed, without nematocyst warts, freckles, or bars; scalpel-shaped, with a narrow abaxial wing c. 1x canal width, and broad adaxial wing c. $2 x$ canal width; inner keel not overhanging at tentacle insertion. Pedalial canal simple, slightly diamond-shaped in cross section throughout length; bend with slight upward-pointing nub forming $90^{\circ}$ corner; not flared at tentacle insertion. Tentacles four, one per pedalium, with a straight base, round in cross section; largely broken off in this specimen, but appearing more or less evenly banded, not of the halo form.

Gonads paired, leaf-like, nearly touching in midline halfway down bell; connected along entire length from stomach to velarium; narrower around and below rhopalium, pendant below rhopalium.

Velarial canals comprising one root per octant branching into three, one or two of which further branch; without lateral diverticula; without warts over the canals. Perradial lappets broadly rounded, tongue-shaped, nearly reaching velarial edge; with an irregular row of warts on each side (Figure 4C), without diverticula. Frenulum comprising a single simple sheet, lacking gelatinous buttresses, reaching about 3/4 the distance toward velarial margin, disappearing at rhopalium.

Rhopalial niche ostium frown-shaped, with a single well developed covering scale each above and below, broadly concave in shape (Figure 4C). Rhopalial horns relatively short, straight, evenly wide throughout their length, nearly vertical in orientation (Figure 4C). Rhopalial windows shallowly convex with a small indentation at the point where the rhopalial stem meets the body wall. Lower median lensed eye round, considerably larger than the dome-shaped upper median lensed eye. Lateral eye spots absent (Figure 4D). Statolith nearly perfectly hemispherical (Figure 4D).

Phacellae lacking. Stomach with numerous parallel folds, possibly indicating great expansion capabilities, or possibly sites of increased surface area for enzyme activity as would normally be found on the gastric phacellae. Mesenteries (Figure 4B) extremely well developed, fully webbed, with flaps extending down about $3 / 4$ the distance to the rhopalial niches, with a barely perceptible cord reaching the rhopalium, running through the center of a transparent strip of tissue. Manubrium cruciform, extending to about half the bell height; mouth with four short, broadly quadrate lips.

Colour: bell transparent and colourless, nematocyst warts faintly reddish, tentacles white, gonads nearly opaque whitish, eyes dark brown. 


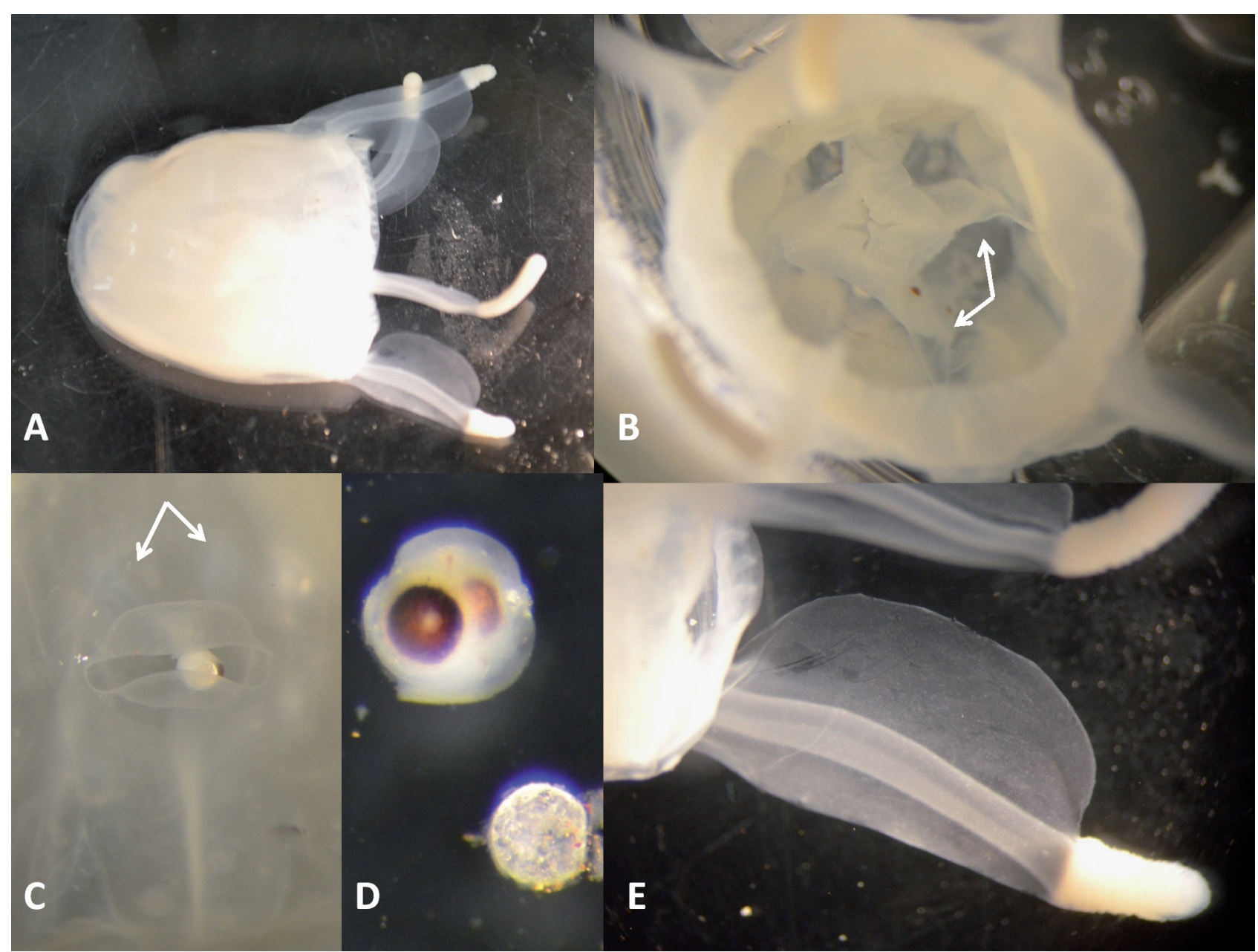

FIGURE 4 Malo bella sp. nov., holotype. A. habitus. B. subumbrellar view of mesenteries (indicated by arrows) and manubrium. C. rhopaliar niche (rhopaliar horns are indicated by arrows); note also perradial lappets with irregular nematocyst warts in lower centre of image. D. rhopalium (above) and statolith (below), dissected away from specimen and rotated such that left side of image would be 'down' in life; note absence of lateral eye spots. E. pedalium.

\section{VARIATION}

The paratypes have halo-form bands similar to those of some Malo kingi specimens, although the holotype does not. The origin and function of these bands remains unclear, as does the exact relationship of the banded and unbanded forms.

The velarial canals of paratype NTM C14617 were earlier interpreted as only two per octant, the adperradial widely bifurcated and the adinterradial narrow and simple (as "Dampier Irukandji" in Gershwin 2005a). These are now reinterpreted as three. However, the canals of this paratype have lateral diverticula whereas those of the holotype do not. One of the paratypes in lot NTM C5143 has a single main velarial canal root in each octant, with four finger-like canals issuing from it, each with numerous lateral diverticula, whereas the holotype has a single root with three canals and no diverticula. These differences are interpreted as intraspecific variation rather than specific distinction; similar canal variation is found in the confamilial Morbakka (Gershwin 2008).

The perradial lappets of paratype NTM C14617 are broadly rounded with large diverticula, and with a single large wart, whereas the holotype has an irregular row of warts on each side and lacks diverticulating canals.

\section{ETYMOLOGY}

The species name, bella, is in triple reference to its small bell-like shape, its beauty, and the Montebello Islands in the Pilbara region of Western Australia, where the species was first found. Noun in apposition.

\section{TYPE LOCALITY}

Approximately $300 \mathrm{~m}$ east of the sandy beach in front of Harold E. Holt Memorial Communications Base (estimated GPS coordinates from Google Earth: $\left.21^{\circ} 53^{\prime} 28.37^{\prime \prime} \mathrm{S}, 114^{\circ} 08^{\prime} 57.47^{\prime \prime} \mathrm{E}\right)$, Exmouth Gulf, Western Australia. 


\section{ECOLOGY}

Very little is known about the ecology of this species; however, the following details were noted at the time the holotype was collected:

- The specimen was moving/swimming in a northerly direction with outgoing tide past a coral bommie;

- Water temperature was reliably estimated at $19-21^{\circ}$;

- Many other plankton reported in the water at the same time including several individuals of another jelly that had same bell shape and size as the Malo specimen, four tentacles approx. 30-40 cm long and a very vibrant pink purple band around the base of bell.

\section{DISTRIBUTION}

Presently only confirmed from Exmouth Gulf and Trimoville Island in the Montebello Islands of the Pilbara region, WA. Photographs and video of Malo specimens taken along Ningaloo Reef and Coral Bay in 2013 appear to be attributable to this species, but are unverified.

\section{NEMATOCYSTS AND STING POTENTIAL}

The tentacular nematocysts of paratype NTM C14617 were figured by Gershwin (2006: pl. 19), with the following features: rice-shaped sub-ovate microbasic p-mastigophores: $31.67-40.47 \times 14.01-16.50 \mu \mathrm{m}(\mathrm{n}=19)$. The cnidome of the holotype was not studied.

The sting potential of this species is not yet known; however, because of its phylogenetic relationship to M. kingi, which is apparently lethal (Gershwin 2007), and M. maxima, which also causes severe Irukandji syndrome (Gershwin 2005b; Li et al. 2011), this species should be regarded as potentially dangerous.

\section{REMARKS}

Malo bella is the smallest species yet described in the genus. It is most similar overall to $M$. kingi (Table 2), in that both have a warty domed body, a $90^{\circ}$ pedalial canal bend, short broad rhopaliar horns, and a single palmate velarial canal root. However, the two species differ in several structural features. First, $M$. kingi has warts over the velarial canals, whereas M. bella does not. Second, the pedalial wings are broader relative to the pedalial canal in M. kingi than in M. bella, and some specimens of the former have nematocyst freckles, whereas $M$. bella does not. Third, the statolith of $M$. kingi is globular with a prominent apical hook, whereas that of $M$. bella is almost perfectly hemispherical. Finally, $M$. bella is smaller at maturity $(20 \mathrm{~mm})$ : specimens of $M$. kingi at the same size are immature.

The halo-form tentacle armament is worthy of discussion. Both M. kingi and M. bella have it, whereas this feature is not known in other species. Whether this represents ontogenetic change or unelucidated phylogenetic distinction or mere individual variation is not clear.

The asymmetrical occurrence of the perradial lappet nematocyst warts are curious. In specimen NTM C14617, these warts occur on the animal's left side of the lappets only, though the warts in the holotype occur asymmetrically on both sides; in the poorly preserved other paratypes, the velarium could not be examined adequately to determine their wart arrangement. Velarial warts are typically either symmetrical on the lappets (e.g. Gerongia rifkinae and Malo kingi, in which the warts occur in rows on both lappets), symmetrical on the velarial canals (e.g. Carukia barnesi, in which the warts occur in a patterned manner on the canals only), or completely random (e.g. the Morbakka species complex,

TABLE 2 Comparison of main diagnostic characters of species in the genus Malo. Abbreviations: Pedalial canal bend $(\mathrm{PCB})$; rhopalial horns $(\mathrm{RH})$; velarial canals $(\mathrm{VC})$; perradial lappets $(\mathrm{PL})$; mesenteries $(\mathrm{MS})$.

\begin{tabular}{|c|c|c|c|c|}
\hline Species & Body & Pedalia & Rhopalia & Velarium \\
\hline Malo maxima & $\begin{array}{l}\approx 50 \mathrm{~mm} \mathrm{BH}, \text { warty, } \\
\text { with flattened apex; } \\
\text { moderate MS }\end{array}$ & $\begin{array}{l}3 \text { nematocyst freckles; } \\
\text { PCB with short blunt } \\
\text { oblique projection }\end{array}$ & $\begin{array}{l}\text { RH short, thick, straight; } \\
\text { statolith globular with } \\
\text { basal indentation }\end{array}$ & $\begin{array}{l}\text { VC } 1 \text { root, } 4 \text { canals, } 4-6 \\
\text { tips; PL with one wart }\end{array}$ \\
\hline Malo kingi & $\begin{array}{l}\approx 30 \mathrm{~mm} \mathrm{BH} \text {, warty } \\
\text { apically, with domed } \\
\text { apex; large MS }\end{array}$ & $\begin{array}{l}\text { With or without } \\
\text { nematocysts; PCB } 90^{\circ}\end{array}$ & $\begin{array}{l}\text { RH short, broad, curved } \\
\text { inward; statolith globular } \\
\text { with basal indentation } \\
\text { and apical tooth }\end{array}$ & $\begin{array}{l}\text { VC } 1 \text { root, palmate, } 4-5 \\
\text { tips; PL with } 2 \text { rows of } \\
3-4 \text { patches }\end{array}$ \\
\hline Malo filipina & $\begin{array}{l}\approx 40 \mathrm{~mm} \mathrm{BH}, \text { warty, } \\
\text { large MS }\end{array}$ & $\begin{array}{l}1 \text { row of round warts; } \\
\text { PCB with 'spike' }\end{array}$ & $\begin{array}{l}\text { RH short, broad, blunt; } \\
\text { statoliths unknown }\end{array}$ & $\begin{array}{l}\text { VC palmate, } 3-4 \text { tips; PL } \\
\text { with } 2 \text { rows of } 2-4 \text { warts }\end{array}$ \\
\hline Malo bella sp. nov. & $\begin{array}{l}\approx 20 \mathrm{~mm} \mathrm{BH} \text {, warty, with } \\
\text { domed apex; large MS }\end{array}$ & $\begin{array}{l}\text { Lacking nematocysts; } \\
\text { PCB } 90^{\circ}\end{array}$ & $\begin{array}{l}\text { RH short, thick, straight; } \\
\text { statolith nearly perfectly } \\
\text { hemispherical }\end{array}$ & $\begin{array}{l}\text { VC } 1 \text { root, } 3-4 \text { canals, } \\
\text { ca } 6 \text { tips; PL with } 2 \\
\text { irregular rows of warts }\end{array}$ \\
\hline
\end{tabular}


in which the warts are scattered among lappets, canals, and intermediate tissues). In this current case, the arrangement of warts is inconsistent with those known thus far.

\section{ACKNOWLEDGMENTS}

Spectacular photos and vivid specimen and sting descriptions were kindly provided by Pat Baker (WAM) and John Totterdell (MIRG Australia) - thank you both! Sincere thanks also to Peter Barnes, Ray De Jong, and Arvid Hogstrom of DPaW for access to the Malo holotype, and to John Keesing for access to the Keesingia holotype. Sincere acknowledgments also to Drs Joanna Strzelecki and Tim Ryan of CSIRO for lab assistance when desperately needed. And a hearty thanks to Jane Fromont of WAM for encouraging and facilitating this paper. This paper benefited from the comments of two reviewers. Part of this research was funded by Environment Australia/Australian Biological Resources Study (ABRS grants 207-63 and 208-82).

\section{REFERENCES}

Agassiz, A. and Mayer, A.G. (1902). Reports of the scientific research expedition to the tropical Pacific. U.S. Fish Comm. St. Albatross, 1899-1900. III. The Medusae. Memoirs of the Museum of Comparative Zoology, Harvard 26(3): 139-176, 14 plates.

Barnes, J.H. (1964). Cause and effect in Irukandji stingings. Medical Journal of Australia 1 (51st Year)(24): 897-904.

Bentlage, B. (2010). Carybdea alata auct. (Cubozoa): rediscovery of the Alatina grandis type. Zootaxa 2713: 52-54.

Bigelow, H.B. (1938). Plankton of the Bermuda Oceanographic Expeditions. VIII. Medusae taken during the years 1929 and 1930. Zoologica, N.Y. 23 (part 2)(5-9): 99-189.

Calder, D. R. 1974. Nematocysts of the coronate scyphomedusa, Linuche unguiculata, with a brief reexamination of scyphozoan nematocyst classification. Chesapeake Science 15: $170-173$.

Chiaverano, L.M., Holland, B.S., Crow, G.L., Blair, L. and Yanagihara, A.A. (2013). Long-term fluctuations in circalunar beach aggregations of the box jellyfish Alatina moseri in Hawaii, with links to environmental variability. PLOS ONE 8(10): e77039.

Collins, A.G., Bentlage, B., Gillan, W.B., Lynn, T.H., Morandini, A.C. and Marques, A.C. (2011). Naming the Bonaire banded box jelly, Tamoya ohboya, n. sp. (Cnidaria: Cubozoa: Carybdeida: Tamoyidae). Zootaxa 2753: 53-68.

Fenner, P.J. and Hadok, J.C. (2002). Fatal envenomation by jellyfish causing Irukandji syndrome. Medical Journal of Australia 177(7): 362-363.

Flecker, H. (1952). Irukandji sting to North Queensland bathers without production of weals but with severe general symptoms. Medical Journal of Australia July 19: 89-91.

Gershwin, L. (2005a). Taxonomy and Phylogeny of Australian Cubozoa. Unpublished PhD thesis, School of Marine Biology and Aquaculture. James Cook University: Townsville. 221 pp., 49 plates.

Gershwin, L. (2005b). Two new species of jellyfishes (Cnidaria: Cubozoa: Carybdeida) from tropical Western Australia, presumed to cause Irukandji Syndrome. Zootaxa 1084: 1-30.

Gershwin, L. (2005c). Carybdea alata auct. and Manokia stiasnyi, reclassification to a new family with description of a new genus and two new species. Memoirs of the Queensland Museum 51(2): 501-523.

Gershwin, L. (2006). Nematocysts of the Cubozoa. Zootaxa 1232: $1-57$.

Gershwin, L. (2007). Malo kingi: A new species of Irukandji jellyfish (Cnidaria: Cubozoa: Carybdeida), possibly lethal to humans. Zootaxa 1659: 55-68.

Gershwin, L. (2008). Morbakka fenneri: a new genus and species of Irukandji jellyfish (Cnidaria: Cubozoa). Memoirs of the Queensland Museum 54(1): 23-33.

Gershwin, L., De Nardi, M., Fenner, P.J. and Winkel, K.D. (2009). Marine stingers: Review of an under-recognized global coastal management issue. Journal of Coastal Management 38(1): 22-41.

Gershwin, L. and Hannay, K.D. (2014). An anomalous cluster of Irukandji jelly stings (Cnidaria: Cubozoa: Carybdeida) at Ningaloo Reef. Records of the Western Australian Museum 29(1): 78-81.

Gershwin, L., Richardson, A.J., Winkel, K.D., Fenner, P.J., Lippmann, J., Hore, R., Avila-Soria, G., Brewer, D., Kloser, R., Steven, A. and Condie, S. (2013). Biology and ecology of Irukandji jellyfish (Cnidaria: Cubozoa). Advances in Marine Biology 66: 1-85.

Hutchins, B. (1994). Jellyfish and the little leatherjacket. Geo Australia 16(1 (Jan/Feb)): 66-75.

Huynh, T.T., Seymour, J., Pereira, P., Mulcahy, R., Cullen, P., Carrette, T. and Little, M. (2003). Severity of Irukandji syndrome and nematocyst identification from skin scrapings. Medical Journal of Australia 178(1): 38-41.

Lewis, C., Bentlage, B., Yanagihara, A., Gillan, W., van Blerk, J., Keil, D.P., Bely, A.E. and Collins, A.G. (2013). Redescription of Alatina alata (Reynaud, 1830) (Cnidaria: Cubozoa) from Bonaire, Dutch Caribbean. Zootaxa 3737(4): 473-487.

Li, R., Wright, C.E., Winkel, K.D., Gershwin, L.A. and Angus, J.A. (2011). The pharmacology of Malo maxima jellyfish venom extract in isolated cardiovascular tissues: A probable cause of the Irukandji syndrome in Western Australia. Toxicology Letters 201: 221-229.

Macrokanis, C.J., Hall, N.L. and Mein, J.K. (2004). Irukandji syndrome in northern Western Australia: an emerging health problem. Medical Journal of Australia 181(11/12): 699-702.

Mariscal, R.N. (1971). Effect of a disulfide reducing agent on the nematocyst capsules from some coelenterates, with an illustrated key to nematocyst classification. In: Lenhoff, H.M., Muscatine L. and Davis L. V., Experimental Coelenterate Biology: 157-168. University of Hawaii Press: Honolulu.

Marsh, L. and Slack-Smith, S. (2010). Field Guide to Sea Stingers. Western Australian Museum: Welshpool, Western Australia.

Southcott, R.V. (1967). Revision of some Carybdeidae (Scyphozoa: Cubomedusae), including a description of the jellyfish responsible for the "Irukandji syndrome". Australian Journal of Zoology 15(3): 651-671.

Stenning, A.E. (1928). Poisoning by Trachymedusae. Medical Journal of Australia 1(18 (May 5, 1928)): 568-569.

Williamson, J.A., Fenner, P.J., Burnett, J.W. and Rifkin, J. (eds) (1996). Venomous and Poisonous Marine Animals: A Medical and Biological Handbook. NSW University Press: Sydney.

MANUSCRIPT RECEIVED 1 NOVEMBER 2013; ACCEPTED 25 MARCH 2014. 